\title{
Tafsir Kontekstual JIL: Telaah atas Konsep Syariat Islam dan Hudūd
}

\author{
Oleh: Cucu Surahman ${ }^{1}$
}

\begin{abstract}
This article examines the views of Jaringan Islam Liberal (Islamic Liberal Networks) on the concept of Islamic Shari'ah law, particularly regarding to their interpretation of hudūd verses.

Through hermeneutical and bibliographical study of several publications and works of JIL, the article concludes that JIL's interpretations of these issues are very contextual. This can be seen from their use of the historical and rational approach to the Qur'an and its interpratation, as well as from the tendency of subjective and ideological agenda in their support of gender equality, human rights and liberalism.
\end{abstract}

\begin{abstract}
Abstrak
Tulisan ini mengkaji pemikiran Jaringan Islam Liberal (JIL) tentang konsep Syariat Islam, terutama mengenai ayat-ayat hudūd.

Melalui kajian hermeneutis-bibliografis atas beberapa publikasi dan karya-karya JIL, tulisan ini berkesimpulan bahwa penafsiran JIL atas isu-isu ini bersifat kontekstual. Hal ini bisa dilihat dari penggunaan mereka terhadap pendekatan historis dan rasional terhadap al-Qur'ān dan penafsirannya, dan juga dari kecenderungan subyektif dan ideologis mereka dalam mendukung agenda kesamaan jender, hak asasi manusia dan liberalisme.
\end{abstract}

Keywords: tekstual dan kontekstual, ḥudūd, rekontekstualisasi, dekontekstualisasi

${ }^{1}$ Dosen Institut Agama Islam Daarussalam, Ciamis. E-mail: cucums@yahoo.com 


\section{Pendahuluan}

Tantangan yang dihadapi oleh para pemikir agama, termasuk para sarjana Muslim, di era modern dan postmodern ini memang sangat berat. Mereka dihadapkan pada berbagai masalah dan isu modernitas yang belum ada pada masa sebelumnya, seperti isu kesetaraan gender, hak asasi manusia, humanisme, liberalisme, sekularisme, pluralisme, dan isu-isu modernitas lainnya.

Hal ini semua menuntut para pemegang otoritas dan cendekiawan agama untuk melakukan pembacaan kembali (rereading) terhadap kitab suci, sumber rujukan agama mereka masing-masing. Bagi para sarjana Muslim modern, pembacaan ulang ini bukan hanya berupa pembacaan yang berpijak pada otoritas teks semata (secara literal), tetapi lebih dari itu mereka berusaha menunjukkan signifikansi dan nilai kontributif teks keagamaan tersebut bagi kehidupan modern yang sedang dihadapi.

Perjalanan sejarah di satu sisi telah melahirkan nilai-nilai dan capaian kumulatifnya, dan teks keagamaan di sisi lain, tetaplah sama seperti sejak masa formatifnya. Kenyataan bahwa teks (nașs) bersifat terbatas sedangkan realitas (waqa'̄i) terus berkembang, menuntut pada sarjana Muslim, khususnya di bidang tafsir al-Qur'ān, untuk melakukan penafsiran (interpretation) yang cocok dengan denyut nadi perkembangan zaman. ${ }^{2}$

Berbeda dengan para mufasir sebelumnya yang lebih banyak bergulat pada tataran bahasa dan perdebatan teologis, ${ }^{3}$ penekanan para sarjana Muslim modern dalam mengkaji al-Qur'ān adalah pada pentingnya melihat teks alQur'ān dalam hubungannya dengan konteks. ${ }^{4}$ Model pendekatan penafsiran yang terakhir ini kini dikenal dengan istilah pendekatan kontekstual. Penafsiran

${ }^{2}$ Abdullah Saeed, The Qur'an: Introduction (New York: Routledge, 2008), 209.

${ }^{3}$ Seperti dalam kitab Al-Kashshäf, ditulis oleh al-Zamakhshari (w. 538 H.) Tafsir al-Qur'an al-Azim, ditulis oleh Ibn Kathir (w. 774 H.), Mafatih al-Ghayb, ditulis oleh Rāzì (w. 606 H.), Anwār al-Tanzīl wa Asrār al-Ta'wīl, ditulis oleh Bayḍāwì (w. 685 H.), Al-Bahrr al-Muhịt, ditulis oleh Abū Hayyan (w. 745 H.), Rūh al-Ma'ānī, ditulis oleh alAlūsi (w.1270 H.), dan masih banyak karya lainnya. Karya-karya tersebut dipandang oleh para sarjana Muslim modern, alih-alih dapat menghadirkan isi kandungan al-Qur'an ke tengah-tengah umat secara lugas dan komprehensif, yang mereka lakukan justru menjauhkan tertangkapnya pesan-pesan al-Qur'an oleh umat, karena mereka lebih sibuk dengan bidang ilmu yang mereka kuasai, terutama dalam bidang bahasa dan teologi.

${ }^{4}$ Pendekatan ini telah digunakan oleh sarjana-sarjana Muslim abad ke-20 seperti: Amin Khūli (w. 1966), Sayyid Quṭb (w. 1966), Ḥusayn al-Ṭabaṭaba'i (w. 1981), Muḥammad al-Ghazali (w. 1996), 'Aisha 'Abd al-Rahmān (w. 1998), dan 'Abd Ḥayy alFarmawi. Lihat Abdullah Saeed, Ed., Approaches to the Qur'an in Contemporary Indonesia. (London, Oxford UP in association with the Institute of Ismaili Studies, 2005), 5 . 
kontekstual ini tampak jelas pada pemikiran dan metodologi ${ }^{5}$ tafsir yang ditawarkan oleh Fazlur Rahman ${ }^{6}$ dan Naṣr Hāamid Abū Zayd. ${ }^{7}$

Di antara ciri penafsiran kontekstual adalah model tafsir ini menekankan konteks sosio-historis dalam proses penafsirannya. Ciri lainnya, tafsir ini lebih melihat nilai etis dari ketetapan legal (the ethico-legal content) al-Qur'ān, daripada makna literalnya. Berbeda dengan tafsir tekstual yang secara ketat mendasarkan pemaknaan teks pada unsur linguistik dan keterangan riwayat, tafsir kontekstual melihat bahwa unsur politik, sosial, sejarah, budaya, dan ekonomi adalah hal-hal penting dalam upaya memahami makna teks (pada saat diturunkan, pada saat teks itu ditafsirkan, dan kemudian pada saat diterapkan). ${ }^{8}$ Berbeda dengan tafsir tradisionalis, ${ }^{9}$ yang cenderung teologis-filosofis, tafsir

${ }^{5}$ Istilah method diambil dari bahasa Yunani methodos yang artinya cara (way). Dalam bahasa Arab, bermakna "tariqah" atau "manhäj." Akan tetapi dalam bidang tafsír, istilah manhāj tampaknya lebih sering pakai daripada tariqah. Lihat 'Ali Iyaz, alMufassirūn wa Manāhijuhum (Teheran: Muassasah Taba'ah, 1919).

${ }^{6}$ Metode tafsir kontekstual Fazlur Rahman terlihat jelas dalam teori Double Movements-nya. Teori tersebut adalah sebagai berikut: gerakan pertama terdiri dari dua langkah (1) penafsir harus memahami arti atau makna suatu pernyataan tertentu dengan mengkaji situasi atau problem (sosial) historis di mana pernyataan tersebut merupakan jawabannya. Langkah ini terdiri dari pemahaman makna al-Qur'ān secara keseluruhan serta berkenaan dengan ajaran-ajaran spesifik yang merupakan respons atas situasisituasi spesifik; (2) menggeneralisasikan jawaban-jawaban spesifik itu dan menyatakannya sebagai pernyataan-pernyataan yang memiliki tujuan-tujuan moral-sosial umum yang dapat ditarik dari teks-teks spesifik dalam sinaran latar belakang sosiohistoris dan rationes legis-nya. Dan gerakan kedua, merupakan proses yang berangkat dari pandangan umum ke pandangan spesifik yang harus dirumuskan dan direalisasikan dalam realitas sekarang. Lihat Fazlur Rahman, Islam and Modernity: Transformation of an Intellectual Tradition (Chicago \& London: The University of Chicago Press, 1984), 6.

${ }^{7}$ Ia adalah salah seorang sarjana Muslim yang mengarahkan penafsirannya untuk melahirkan tafsir al-Qur'ān baru yang menekankan signifikansi dan relevansi teks bagi audien kontemporer. Dalam istilah Abū Zayd upaya ini disebut pembacaan produktif (alqirā'ah al-muntijah) atas al-Qur'ān. Abū Zayd, Naqd al-Khitāb al-Dīnī (Kairo: Sina li alNashr, 1992), 115. Terkait tafsir kontekstual, menurut Abū Zayd, sebuah penafsiran kontekstual (al-qirā'ah al-siyāqiyyah) harus mengikuti dua langkah, yaitu, pertama, kembali pada makna dalam konteks historis dan kultural teks (tärikhiyyat al-dalālah); dan kedua, menerapkan makna signifikansi (maghza) dari teks tersebut dalam konteks kontemporer/kekinian. Lihat Yusuf Rahman, "The Hermeneutical Theory of Nasr Hamid Abū Zayd," (McGill University Montreal, PhD Dissertation, 2001), 155-156 dan Abū Zayd, al-Naș wa al-Sultah wa al-Haqiqah: al-Fikra al-Dinī bayna al-Irädah al-Ma'rifah wa Irādah al-Haymanah (Beirut: Al-Markaz al-Thaqāfì al-'Arabī, 1995), 239.

${ }^{8}$ Abdullah Saeed, Interpreting the Qur'an: Toward a Contemporary Approach (Oxford: Routledge, 2006), 3.

9 Secara tradisional, metode tafsir al-Qur'an-berdasarkan sumbernya-biasa diklasifikasikan ke dalam tiga kategori: tafsir dengan riwayat (tafsir bi al-riwāyat); tafsir dengan akal (tafsir bi al-ra'y); dan tafsir dengan isyarat (tafsir bi al-isharāh). Al-Farmawi membagi metode tafsir ke dalam empat model, yaitu: tahlili (metode analitik); ijmali 
kontekstual lebih cenderung sosiologis, aksiologis, dan antropologis, karena tujuannya yang ingin memenuhi kebutuhan kaum Muslim di era kontemporer sekarang ini. ${ }^{10}$

Kecenderungan ini pulalah yang terjadi pada JIL ketika mereka memahami konsep Syariat Islam, termasuk ketika mereka menafsirkan ayatayat hudūd. Bagi mereka, konsep Syariat Islam bukanlah sebuah doktrin yang statis, tetapi ia berkembang sesuai dengan konteks zaman. Penerapan Syariat Islam, bagi JIL bukan dalam arti penerapan fikih hudūd (hukum pidana Islam klasik) yang historis itu, tapi lebih pada penerapan semangat etis keagamaannya (religio-etis).

\section{Sekilas tentang JIL}

JIL (Jaringan Islam Liberal) adalah sebuah jaringan intelektual di Indonesia yang mempromosikan gagasan Islam liberal. JIL didirikan oleh para aktivis Utan kayu, ${ }^{11}$ di Jakarta pada 8 April 2001. Anggota-anggotanya, baik yang merupakan aktivis struktural, partisipan, maupun para tokoh rujukan (senior), merasa memiliki kesamaan dalam hal perlunya mempromosikan gagasan liberalisme Islam, yang mencakup di dalamnya isu demokrasi,

(metodel global); muqāran (metode perbandingan); dan maudū'i (metode tematik). Lihat: Farid Essack, The Qur'an: A User's Guide (Oxford: Oneworld Publication, 2007), 142. Sistem pembagian ini didasarkan pada cara bagaimana sebuah proses penafsiran itu dilakukan dan disajikan. Lihat: Abdul Hayy al-Farmawi, Al-Bidāyah fí Tafsìr alMaudūíi, (Kairo: Dār Kutub, 1977).

${ }^{10}$ Abdullah Saeed, Interpreting the Qur'ann: Towards a Contemporary Approach, 4. Abdullah Saeed membagi sarjana tafsir al-Qur'an pada tiga kelompok: (1) tekstualis, (2) semi-tekstualis, dan (3) kontekstualis. Klasifikasi ini didasarkan pada sejauh mana seorang penafsir: (1) mendasarkan penentuan makna teks hanya kriteria linguistik, dan (2) mempertimbangkan konteks sosio-historis al-Qur'ān dan konteks kontemporer sekarang ini. Tekstualis cenderung mengikuti teks secara ketat dan mengadopsi pendekatan literal terhadap teks. Bagi tekstualis, bukannya al-Qur'ān yang harus mengikuti tuntutan zaman, justru al-Qur'ānlah yang harus membimbing kebutuhan zaman (modern). Bagi mereka al-Qur'ān itu sudah tetap dan bersifat universal. Mereka yang termasuk tekstualis ini adalah kelompok Traditionalis dan Salafi. Sementara semitekstualis adalah mereka yang mengikuti Tekstualis dalam hal penekanannya pada makna linguistik dan pengabaian terhadap konteks sosio-historis, tetapi mereka mengemasnya dalam istilah-istilah modern, yang kadang-kadang disampaikan secara apologetik. Di antara yang termasuk semi-tekstualis ini adalah Ikhwān al-Muslimīn (Mesir) dan Jami'at Islami (Pakistan). Lihat Abdullah Saeed, Interpreting the Qur'an: Towards a Contemporary Approach, 1-4.

${ }^{11}$ Mereka adalah Goenawan Mohamad, Ahmad Sahal, Nong Darol Mahmada, Ulil Abshar Abdalla, Ihsan Ali Fauzi, Hamid Basyaib, Taufik Adnan Amal, Saiful Mujani dan Luthfi Assyaukanie. Lihat Ramy el-Dardiry, "Islam Encountering Enlightenment: Clash or Symbiosis?; A Comparative Analysis of the Dutch and Indonesian Discourse on Liberal Islam" (The University of Twente, makalah, tidak diterbitkan), 8. Lihat footnote. 
pemisahan antara agama dan negara, kebebasan berfikir, kesetaraan sosial, hakhak perempuan dan minoritas, dan progresifitas manusia. ${ }^{12}$

Sejak didirikannya, JIL telah mencoba menafsirkan al-Qur'an sesuai dengan ide-ide liberalisme Islam yang mereka yakini, yaitu Islam yang dipahami secara liberal berdasarkan prinsip-prinsip: (1) terbukanya pintu ijtihad dalam seluruh dimensi Islam; (2) penafsiran yang menitik-beratkan pada aspek etikareligius, dan bukan pada makna tekstual-literalnya; (3) percaya pada kebenaran yang relatif, terbatas, dan temporal; (4) mengusung kebebasan menjalankan keyakinan agama; (5) pemihakan pada kaum tertindas dan pihak minoritas; dan (6) pemisahan antara urusan agama dan urusan dunia.

Dengan membentuk jaringan ini JIL bermaksud untuk, pertama, mengembangkan penafsiran yang liberal atas Islam sesuai dengan prinsipprinsip JIL dan kemudian mempromosikan dan menyebarkannya kepada masyarakat; kedua, mendorong bagi terciptanya ruang bagi dialog yang bebas dari segala bentuk tekanan; dan ketiga, membuat struktur sosial-politik yang adil dan berkemanusiaan di Indonesia. ${ }^{13}$

Secara historis, kemunculan JIL merupakan respon atau gerakan tandingan (counter movement) terhadap gerakan-gerakan fundamentalis-radikal di Indonesia yang mengemuka tidak lama setelah lengsernya Suharto pada tahun $1998 .{ }^{14}$ Dalam posisinya sebagai kelompok yang memperjuangkan ruang publik (public sphere) di Indonesia, JIL berperan sebagai counter discourse bagi kelompok-kelompok radikal-konservatif Muslim yang menyerukan penerapan

12 Secara teknis, istilah "Islam liberal" yang digunakan JIL pada awalnya dipopulerkan oleh seorang sarjana Muslim India Asaf Ali Asghar Fyzee, di tahun 1950an. Istilah tersebut menjadi tambah populer di Indonesia melalui dua buku, yaitu Islamic Liberalism: a Critique of Development Ideologies (Chicago and London: The University of Chicago Press, 1988) yang ditulis oleh Leonard Binder, dan Liberal Islam: a Source Book (New York and Oxford: Oxford University Press, 1998) yang diedit oleh Charles Kurzman. Disusul kemudian dengan diterbitkannya buku Greg Barton yang berjudul Gagasan Islam Liberal di Indonesia: Pemikiran Neo-Modernisme Nurcholish Madjid, Djohan Effendi, Ahmad Wahib, dan Abdurrahman Wahid, 1968-1980 (Jakarta: Pustaka Antara-Paramadina, 1999).

${ }^{13}$ Lihat http://islamlib.com/en/pages/about/. Diakses pada hari Rabu 1 Mei 2013.

${ }^{14}$ Ahmad Bunyan Wahib, "Liberal Islam in Indonesia: The Attitude of Jaringan Islam Liberal Towards Religous Freedom and Pluralism" (Leiden University: MA Thesis, 2004), 10; Ahmad Ali Nurdin, "Islam and State: A Study of The Liberal Islamic Network in Indonesia, 1999-2004," New Zealand Journal of Asian Studies 7, 2 (December, 2005): 20-39, 21; Akh. Muzakki, "Current debates in the post Soeharto Indonesian Islam: Examining the Intellectual Base of Liberal and Anti-liberal Islamic Movement," Jurnal Al-Jāmi 'ah, Vol. 45, No. 2, (2007), 322. 
syari'ah dan pembentukan negara Islam Indonesia. ${ }^{15}$ Bagi JIL, Indonesia adalah bangsa majemuk/plural yang membutuhkan ruang publik. Apapun yang menyangkut urusan bersama harus dimusyawarahkan secara bebas dan demokratis. Selama keberadaannya, JIL terus mendukung sistem demokrasi, kebebasan, dan kesetaraan sosial.

Secara ideologis, terbentuknya JIL dapat dilihat sebagai kristalisasi dan kelanjutan dari pemikiran dan gerakan Islam sebelumnya, baik dalam lingkup Indonesia secara khusus maupun di dunia secara umum. ${ }^{16}$ Ide liberalisme Islam sebagai ciri khas JIL misalnya, tidak bisa dilepaskan dari gagasan dan pemikiran para sarjana Muslim sebelumnya. Mengikuti para pendahulunya, JIL berpendapat bahwa agar Islam cocok dengan tuntutan era kontemporer, maka ia harus ditafsirkan secara substansial dan kontekstual.

Dalam skala internasional, gagasan Islam liberal dapat kita lihat dalam pemikiran seperti al-Taḥtawī, Jamāl al-Dīn al-Afghanī, Sayyid Aḥmad Khan, Muhammad Abduh, Muhammad Rashīd Riḍa, Ali 'Abd al-Rāziq. Fazlur Raḥman, Muḥammad Abed al-Jabirī, Naṣr Hamīd Abū Zayd, 'Abd al-Karīm Soroush, Fatima Mernissi, Muhammad Shahrour, Moḥamed Arkoun, Asgar Ali Engineer, 'Abdullāhi Aḥmad al-Na'īm, Ḥasan Ḥanafí, dan Farid Essack. Mereka semua bertemu dalam titik episentrum pemikiran yang sama yaitu menyerukan untuk berijtihad, menghindari taklid, dan berusaha menafsirkan teks Islam secara substansial dan kontekstual, agar ia sesuai dengan tuntutan era modern.

Di Indonesia, gagasan Islam liberal dapat kita telusuri akar historisnya paling tidak sejak tahun 1970-an, ketika Nurcholish Madjid menulis sebuah artikel berjudul "Keharusan Pembaharuan Pemikiran Islam dan Masalah Integrasi Umat". Dalam artikel tersebut Madjid mulai memperkenalkan ide liberalisasi, sekularisasi, dan modernisasi Islam. ${ }^{17}$ Karena pemikiranpemikirannya yang sangat berpengaruh, maka para aktivis JIL mengakui apabila

${ }^{15}$ Ahmad Ali Nurdin, "Islam and State: A Study of The Liberal Islamic Network in Indonesia, 1999-2004," 22; Akh. Muzakki, "Contestation between Liberalism and Anti-liberalism in the Reformasi Indonesian Islam: Jaringan Islam Liberal and Media Dakwah" (Makalah, tidak diterbitkan), 67.

${ }^{16}$ Muhamad Ali, "The Rise of the Liberal Islam Network (JIL) in Contemporary Indonesia" The American Journal of Islamic Social Sciences 22:1, 4.

${ }^{17}$ Nurcholish Madjid, Islam Kemodernan dan Keindonesiaan (Bandung: Mizan, 2008), new edition, 225-259; Lihat juga Adnin Armas, Pengaruh Kristen-Orientalis terhadap Islam Liberal: Dialog Interaktif dengan Aktivis Jaringan Islam Liberal (Jakarta: Gema Insani Press, 2003), 15. 
dikatakan bahwa Nurcholish Madjid adalah lokomotif intelektual bagi wacana Islam liberal di Indonesia sekarang ini. ${ }^{18}$

Selain Nurcholish Madjid, gagasan Islam liberal di Indonesia juga dapat kita temukan pada para sarjana Muslim seperti Harun Nasution, A. Mukti Ali, Munawir Sjadzali, Abdurrahman Wahid, Djohan Effendy, Ahmad Wahib, Ahmad Syafi'i Ma'arif dan Dawam Rahardjo, untuk menyebutkan beberapa. Dalam pemikiran keislamannya, mereka cenderung menekankan Islam yang substantif dan inklusif.

Sebagai fenomena sosial, kemunculan dan keberadaan JIL dapat dilihat sebagai produk wacana (product of discourse). ${ }^{19}$ Pada awal kelahirannya, JIL merupakan sebuah respon terhadap kelompok-kelompok fundamental-radikal, tetapi karena ide-idenya yang liberal dan tidak biasa, maka pada gilirannya JIL menjadi objek respon. Pada perkembangannya, JIL cenderung menjadi objek kritikan. Oleh karena itulah, sebagian gagasan-gagasan JIL adalah hasil dari atau termotivasi oleh kritikan-kritikan ini, termasuk dalam hal ini metode tafsirnya. Gagasan metodologi tafsir JIL sesungguhnya termotivasi oleh banyaknya kalangan yang mempertanyakan epistemologi yang mereka gunakan dalam proses penetapan hukum (istinbät al-ḥukm).

\section{Pemikiran Tafsir JIL}

Dalam buku Metodologi Studi al-Qur'an, ${ }^{20}$ JIL menawarkan sebuah metode dan pendekatan dalam memahami dan menafsirkan al-Qur'ān. Dalam buku ini, ada beberapa hal yang menarik untuk kita kaji. Pertama, terkait cara memandang al-Qur'an; kedua, terkait metode bagaimana menafsirkan alQur'an; dan ketiga, terkait tujuan dan hasil penafsirannya. Dengan pengetahuan tentang ketiga hal tersebut, kita akan dapat memahami kenapa JIL bisa sampai pada kesimpulan-kesimpulan yang berbeda dengan mainstream dan cenderung

${ }^{18}$ Ramy el-Dardiry, Islam Encountering Enlightenment: Clash or Symbiosis?, 17. Untuk mengetahui lebih jauh tentang gagasan Islam liberal di Indonesia, lihat: Greg Barton, Gagasan Islam Liberal di Indonesia: Pemikiran Neo-Modernisme Nurcholish Madjid, Djohan Effendi, Ahmad Wahib, dan Abdurrahman Wahid, 1968-1980 (Jakarta: Pustaka Antara-Paramadina, 1999).

${ }^{19}$ Muhamad Ali, "The Rise of the Liberal Islam Network (JIL)," 21.

${ }^{20}$ Buku ini ditulis oleh tiga pemikir dan aktivis JIL, yaitu: Abd Moqsith Ghazali, Luthfi Assyaukanie, and Ulil Abshar-Abdalla. Lihat Metodologi Studi al-Qur'an (Jakarta: Gramedia, 2009). Selain dari buku ini, sebelumnya JIL juga sudah menerbitkan beberapa buku, di antaranya: Wajah Liberal Islam di Indonesia (Jakarta: JIL, 2002), yang diedit oleh Luthfi Assyaukanie; dan Ijtihad Islam Liberal: Upaya Merumuskan Keberagamaan yang Dinamis (Jakarta: JIL, 2005), yang diedit oleh Abd Moqsith Ghazali. 
menjadi kontroversi, termasuk dalam memahami konsep Syariat Islam dan ayatayat hudūd.

Pertama, terkait cara memandang al-Qur'an. Menurut JIL, agar al-Qur'ān bisa dipahami dengan tepat, maka ia harus dikaji secara historis. ${ }^{21}$ Oleh karena itulah maka JIL memahami teks al-Qur'ān dalam konteks historisnya, yaitu pada waktu ia diwahyukan (process of revelation), ditulis (process of codification) dan disebarkan (process of dissemination).

Menurut JIL, wahyu seharusnya jangan dipandang sebagai teks yang sempurna pada saat ketika ia diturunkan. Setiap kitab suci adalah hasil proses panjang pengumpulan, pengeditan, modifikasi dan kodifikasi dari bentuk awalnya yang terserak sampai pada bentuk akhirnya seperti yang kita ketahui sekarang ini. ${ }^{22}$

Terkait konsep wahyu ini, JIL juga mengkritik konsep pewahyuan seperti yang biasa dijelaskan oleh para sarjana klasik, yaitu sebagai proses pengkopian - di mana al-Qur'ān yang diturunkan kepada Nabi melalui Jibril, adalah kopi dari al-Qur'an yang komplit yang ada di lawh al-mahfuz. ${ }^{23}$ JIL menolak pendapat ini, karena menurutnya, pemahaman tersebut akan mengarah pada keyakinan bahwa pesan Tuhan itu diwahyukan secara literal (harfiyyah) dan, konsekuensinya, teks (Arab) al-Qur'ān seperti yang kita dapati sekarang adalah dari Tuhan. Menurut Luthfi Assyaukanie, salah seorang tokoh JIL, konsep yang mengatakan bahwa al-Qur'ān adalah kitab yang diturunkan secara literal (lafz̧an) dan makna (ma'nan) hanyalah imajinasi teologis (al-khayāl aldinî) yang dibuat oleh para sarjana Muslim sebagai bagian dari proses formalisasi doktrin-doktrin Islam. ${ }^{24}$

Berbeda dengan pandangan konvensional yang melihat Nabi Muhammad sebagai agen yang pasif dalam proses pewahyuan, bagi JIL, Nabi berperan aktif dalam mentransformasikan ide Tuhan ke dalam bahasa manusia (bahasa Arab). Oleh karena itu, teks al-Qur'an menurut JIL, sejatinya adalah ujaran atau

${ }^{21}$ Bagi JIL, historisitas al-Qur'an ini didasarkan pada empat hal: pertama, Tuhan telah memilih bahasa manusia (Arab) sebagai alat komunikasi antara Tuhan dan Muhammad; kedua, keterlibatan Nabi Muhammad sebagai penerima dan sebagai penafsir telah sama-sama menentukan proses pengujaran dan tekstualisasi al-Qur'an; ketiga, prinsip graduasi (tajrid) yang digunakan oleh al-Qur'an dalam mengejawantahkan ajarannya; dan keempat, sejak turunnya (tanzī), al-Qur'an telah berdialog dengan realitas. Lihat Abd Moqsith Ghazali, et.al., Metodologi Studi Al-Qur'an,142-144.

${ }^{22}$ Abd Moqsith Ghazali, et.al., Metodologi Studi Al-Qur'an, 70.

${ }^{23}$ Lihat Burhan al-Din Muhammad ibn Abd Allāh al-Zarkashi, al-Burhān fì 'Ulūm al-Qur'ān (Beirut: Dār al-Ma'ārif li al-Tibā'ah wa al-Nashr, 1972), vol. 1, 299.

${ }^{24}$ Lihat Luthfi Assyaukanie, "Merenungkan Sejarah Al-Qur'an," dalam Abd. Moqsith Ghazali, ed., Ijtihad Islam Liberal, 1. 
tekstualisasi Nabi atas wahyu. ${ }^{25}$ Pendapat ini menggiring pada pandangan bahwa teks al-Qur'ān itu tidak sakral, yang sakral itu hanya maknanya. ${ }^{26}$

Pandangan JIL tersebut tidaklah mengherankan karena metode pendekatan mereka dalam memahami konsep wahyu, kodifikasi-unifikasi, dan diseminasi al-Qur'ān, adalah historis, antropologis, dan humanis. Melalui pendekatan seperti ini, JIL ingin menunjukkan bahwa proses pembukuan dan pembakuan al-Qur'ān sebagai kitab yang suci dan sakral seperti yang kita yakini sekarang ini adalah hasil dari proses perjalanan panjang sejarah manusia (Muslim). ${ }^{27}$

Kedua, terkait metode bagaimana menafsirkan al-Qur'ān. Berdasarkan pada kajian atas hakikat dan historisitas teks al-Qur'ān, maka JIL seakan "meragukan" keabsolutan teks al-Qur'an. Oleh karena itulah maka JIL kemudian menyarankan untuk menafsirkan al-Qur'an secara substansial, yaitu dengan mempertimbangkan aspek ethico-legis (semangat etis) dari al-Qur'an sebagai pusat edar penafsiran. Sambil menolak pemahaman literal-tekstual ${ }^{28}$ terhadap al-Qur'ān, JIL menawarkan apa yang mereka sebut dengan penafsiran di balik teks (beyond text interpretation).

Terkait metodologi tafsirnya ini, JIL membagi ayat-ayat al-Qur'ān pada dua bagian: pertama, ayat-ayat fundamental (ușūt) dan kedua, ayat-ayat cabang (fususut). Apabila yang pertama bersifat absolut dan tidak bisa berubah, maka yang kedua, menurut JIL, bisa ditafsirkan dan diubah sesuai dengan perkembangan sejarah manusia, atau dengan apa yang mereka sebut dengan

${ }^{25}$ Abd Moqsith Ghazali, et.al., Metodologi Studi Al-Qur'an, 143-151.

${ }^{26}$ Pendapat ini dipegang oleh Abū Hanifah (w. 148/767). Berdasarkan argumentasi ini, dia membolehkan menggunakan terjemah al-Qur'an dalam shalat. Lihat Mahmud Shaltut, al-Islām Aqīdah wa Sharī 'ah (Beirut: Dār al-Fikr, 1996), 483. Secara teologis, pandangan JIL tentang hakikat al-Qur'an ini lebih dekat ke Mu'tazilah yang meyakini bahwa al- Qur'an itu baru (hadith) dan makhluk (makhluq), dari pada ke Ash'ariah yang meyakini bahwa al-Qur' an itu abadi (qadim) dan bukan makhluk (ghair makhluq). Lihat Qaụi 'Abd al-Jabbār, Sharh fi al-Ușul al-Khamsah (Cairo: Maktabah Wahbah, tt.), 525; Abū al-Ḥasan al-Ash'arì, al-Ibānah 'an Usūl al-Diyānah (Kairo: Dār al-Tabā'ah Darb alAtrak, tt), 17-34; dan al-Shahrashtani, Kitab Nihāyah al-Iqdām fi 'Ilm al-Kalām, 268340 .

${ }^{27}$ Bagi JIL, al-Qur'an yang ada sekarang ini bukanlah hanya merupakan campur tangan Tuhan saja, tetapi juga melibatkan Nabi, para penafsir, dan umat secara historis. Lihat Abd Moqsith Ghazali, et.al., Metodologi Studi Al-Qur'an, 3 dan 70.

${ }^{28}$ Penafsiran Tekstualis adalah penafsiran yang mendasarkan pada makna literal teks al-Qur'an. Penafsirannya terutama didasarkan pada analisis kebahasaan daripada analisis historis. Pendekatan ini dilandaskan pada keyakinan bahwa bahasa al-Qur'an memiliki rujukan yang konkrit dan tidak berubah, serta makna yang cocok bagi segala konteks zaman. Lihat Abdullah Saeed, The Qur'an: Introduction, 220. 
"akal publik" ('aql al-mujtama ). ${ }^{29}$ Lebih jauh JIL menjelaskan bahwa selain dari ayat-ayat tentang ritual seperti shalat, puasa, dan haji, serta aturan terkait makanan dan minuman, semua ayat-ayat hukum yang diturunkan di Madinah harus dilihat sebagai ayat-ayat temporal-kontekstual dan terbatas pada kehidupan masyarakat Arab pada abad ke-7 Hijriah.

Mengikuti teori hermeneutika ${ }^{30}$ double movements Fazlur Rahman, ${ }^{31}$ atau teori Tafsir Kontekstual yang ditawarkan Taufik Adnan Amal dan Syamsu Rizal Panggabean, ${ }^{32}$ JIL mengajukan langkah-langkah penafsiran sebagai berikut: pertama, dimulai dengan memahami konteks ayat (di mana, kapan, dan dalam situasi seperti apa ayat itu diturunkan). Terkait hal ini, menurut JIL, untuk bisa menafsirkan al-Qur'ān, seorang penafsir harus mengetahui konteks (sejarah), karena teks itu tidak cukup dengan sendirinya (self-sufficient). ${ }^{33}$ Proses ini dimaksudkan untuk menemukan prinsip-prinsip dasar hukum Islam (maqāsid al-sharī'ah), atau dalam istilah Rahman, semangat dasar (élan vital) pewahyuan al-Qur'ān.

Kedua, ketika maqāsid al-sharī'ah-nya sudah diketahui, maka teks harus dilepaskan dari konteks Arabnya (dekontekstualisasi); dan ketiga, mengkontekstualisasikan maqāsid al-shari 'ah tersebut dalam konteks partikular (bukan Arab) kontemporer. Tiga proses (kontekstualisasi, de-kontekstualisasi, dan rekontekstualisasi) ini, menurut JIL, adalah kerangka kerja (framework) dalam proses penafsiran al-Qur'ān yang tak pernah akan berhenti. ${ }^{34}$

${ }^{29}$ Abd Moqsith Ghazali, et.al., Metodologi Studi Al-Qur'an, 164-166.

${ }^{30}$ Istilah "hermeneutics" berasal dari kata kerja Yunani hermêneuein, yang artinya "menafsirkan," atau kata benda hermêneia, "penafsiran." Istilah hermeneutics merujuk pada suatu ilmu interpretasi yang umumnya digunakan sebagai: 1 . Teori penafsiran bibel (biblical exegesis); 2. Metodologi filologi umum; 3. Ilmu semua pemahaman linguistic; 4. Dasar metodologi bagi ilmu-ilmu humaniora (Geisteswissenschaften); 5. fenomenologi wujud (existence) dan pemahaman eksistensial; dan 6. Sistem interpretasi. Lihat Richard E. Palmer, Hermeneutics: Interpretation Theory in Schleiermacher, Dilthey, Heidegger, and Gadamer (Evanston, Illinois: Northwestern University Press, 1969), 12 dan 33. Di antara sarjana yang telah mengaplikasikan hermeneutika adalah Fazlur Rahman (w. 1988), Mohamed Arkoun (w. 2010), Nașr Abū Zayd (w. 2010), Fatima Mernissi, Abdullahi al-Naim, dan Farid Essack. Mereka telah mencoba menawarkan pendekatan kontekstual dalam menafsirkan al-Qur'an dengan mengambil manfaat dari hermeneutika modern. Lihat Suha Taji-Farouki (ed.), Modern Muslim Intellectuals and the Qur'ān (Oxford: Oxford University Press, 2004).

31 Fazlur Rahman, Islam and Modernity: Transformation of an Intellectual Tradition (Chicago: University of Chicago Press, 1982), 6-7.

32 Taufik Adnan Amal dan Syamsu Rizal Panggabean, Tafsir Kontekstual alQur'an: Sebuah Kerangka Konseptual (Bandung: Mizan, 1989).

${ }^{33}$ Abd Moqsith Ghazali, et.al., Metodologi Studi Al-Qur'an, 123.

${ }^{34}$ Abd Moqsith Ghazali, et.al., Metodologi Studi Al-Qur'an, 155. 


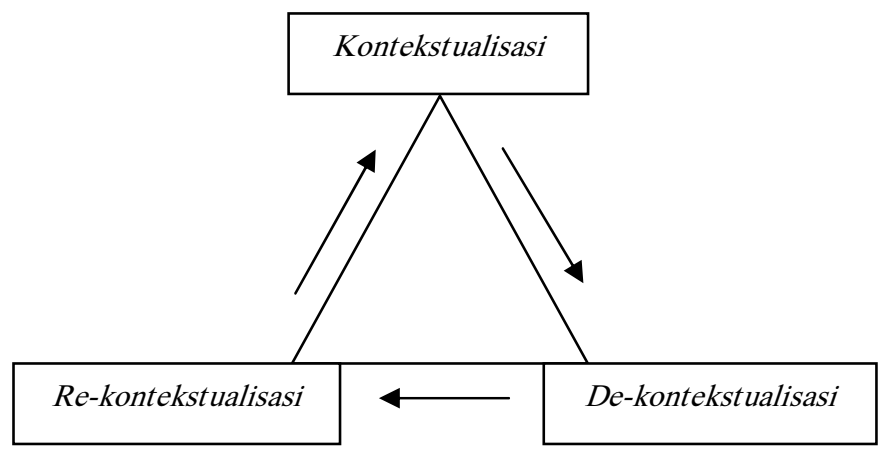

(Segi Tiga Gerak Penafsiran JIL)

Seraya mengikuti metode tafsir kontekstual, JIL mengkritik metodologi tafsir tradisional (konvensional), ${ }^{35}$ dengan beberapa alasan: pertama, metodologi klasik tersebut kurang apresiatif terhadap kemampuan akal (publik) manusia untuk memilih dan merubah aturan hukum Islam formal yang tidak relevan. Dalam metodologi klasik, ketika teks dan akal publik bertentangan, maka yang terakhir harus dikalahkan;

Kedua, metode klasik itu kurang menghargai kemampuan manusia untuk merumuskan konsep mașlahah, bahkan untuk kepentingan manusia sendiri. Dalam Ushul Fikih klasik misalnya, manusia tidak memiliki posisi apa-apa kecuali sebagai objek hukum yang lemah (mukallaf); dan ketiga, metodologi klasik yang menggunakan pendekatan tekstual secara ketat, yang dalam istilah JIL disebut bibliolatry ("penyembahan" terhadap teks) dan mengabaikan realitas. Dalam metodologi klasik, teks adalah poros dari proses penafsiran. Aktivitas ijtihad hanya bisa dilakukan dalam ranah teks tersebut, dan setiap ijtihad yang jauh melampaui teks maka dianggap sebagai sebuah penyimpangan. $^{36}$

Tidak seperti metodologi klasik yang meletakkan akal setelah teks, JIL memposisikan maqāsid pada tingkatan paling atas. Bagi JIL, prinsip utama dalam menafsirkan teks adalah maqāsid al-sharī ah (tujuan utama dari ajaran

35 Secara tradisional, metode tafsir al-Qur'ān—berdasarkan sumber-nya-biasa diklasifikasikan ke dalam tiga kategori: tafsir dengan riwayat (tafsir bi al-riwāyat); tafsir dengan akal (tafsir bi al-ra'y); dan tafsir dengan isyarat (tafsir bi al-isharāh). Al-Farmawi membagi metode tafsir ke dalam empat model, yaitu: tahlili (metode analitik); ijmali (metodel global); muqāran (metode perbandingan); dan maudūi (metode tematik). Lihat: Farid Essack, The Qur'an: A User's Guide (Oxford: Oneworld Publication, 2007), 142. Sistem pembagian ini didasarkan pada cara bagaimana sebuah proses penafsiran itu dilakukan dan disajikan. Lihat: Abd al-Hayy al-Farmawī, Al-Bidaya fí Tafsir al-Mauḍu $\bar{i}$ (Kairo: Dār Kutub, 1977).

${ }^{36}$ Abd Moqsith Ghazali, et.al., Metodologi Studi Al-Qur'an, 140. 
Islam). Maqāṣid adalah sumber dari segala sumber hukum, ${ }^{37}$ dan untuk menjaga maqāsid al-shari' 'ah dalam proses penafsiran, JIL menawarkan tiga prinsip penafsiran al-Qur'an:

1). Al-'ibrah bi al-maqāsid lā bi al-alfāz. Dengan prinsip ini, JIL ingin mengatakan bahwa pengambilan hukum harus berdasarkan maqāsid alshari'ah, jangan berdasarkan zahir lafadz-nya;

2). Jawāz naskh nuṣuṣ (al-juz’iyyah) bi al-maṣlaḥah. Dengan kaidah ini, JIL ingin menegaskan bahwa maṣlahah (kebaikan umum) boleh menghapus ketentuan hukum yang termaktub dalam teks partikular (temporal), dan

3). Tanqiḥ al-nuṣuṣ bi 'aql al-mujtama' yajūz. Bahwa akal publik memiliki kewenangan untuk menyortir sejumlah ketentuan partikular agama menyangkut urusan-urusan publik, sehingga ketika ada pertentangan antara akal publik dengan bunyi harfiah teks ajaran, maka akal publik memiliki otoritas untuk mengedit, menyempurnakan, dan memodifikasinya. ${ }^{38}$

JIL mengkritik pengusung supremasi kata (lafZ) yang kini tampak dan menjadi mainstream di dunia Muslim. Untuk itu JIL mencoba mereformulasi teori qat ${ }^{\prime} \bar{i}$ dan zann $\bar{i}$ klasik yang hanya didasarkan pada kata (lafz) saja. Bagi JIL, teori qat ${ }^{\prime} \bar{i}$ dan zanni $\bar{i}$ harus memperhatikan juga unsur nilai (value). ${ }^{39}$ Mengikuti Rahman, JIL mengatakan bahwa pembagian ini harus mempertimbangkan unsur etika keagamaan (religio-ethics) sebagai élan vital ajaran Islam. JIL sejalan dengan Masdar F. Mas'udi, yang mengatakan bahwa ayat-ayat qat ' $\bar{i}$ adalah ayat-ayat yang berisi nilai-nilai universal yang tidak akan berubah dengan berubahnya waktu dan tempat, sedangkan ayat-ayat zann $\vec{i}$ adalah ayat-ayat yang berkaitan dengan cara bagaimana ayat-ayat universal itu diimplementasikan pada konteks tertentu. ${ }^{40}$

${ }^{37}$ Abd Moqsith Ghazali, et.al., Metodologi Studi Al-Qur'an, 150.

${ }^{38}$ Abd Moqsith Ghazali, et.al., Metodologi Studi Al-Qur'an, 152-170.

${ }^{39}$ Abd Moqsith Ghazali, et.al., Metodologi Studi Al-Qur'an, 130.

${ }^{40}$ Abd Moqsith Ghazali, et.al., Metodologi Studi Al-Qur'an, 131. 
Mengikuti al-Na'im dan Maḥmud Muhammad Ṭaha (w. 1985), ${ }^{41}$ JIL melihat bahwa ayat-ayat Makiyyah berisi prinsip-prinsip Islam universal dan oleh karena itu dianggap sebagai ayat-ayat qat $\bar{i}$, sedangkan ayat-ayat Madaniyah lebih berisi tentang bagaimana mempraktekkan konsep-konsep etis universal tersebut di dalam konteks Madinah dan oleh karenanya bisa diklasifikasikan sebagai ayat-ayat zanni. Apabila yang pertama itu dapat menghapus (nāsikh), maka yang kedua dapat dihapus (mansūkh).

Dengan prinsip al-'Ibrah bi al-Maqāssid lā bi al-Alfä, JIL ingin mengatakan bahwa hal yang terpenting dalam proses pengambilan hukum (istinbat al-ḥukm) adalah maqāsid (tujuan utama), bukan makna literal dari teks. Bagi JIL, maqāsid adalah poros (axis) dalam proses penafsiran.

Maqāsid yang dimaksud JIL di sini adalah maqāsid al-sharī'ah (tujuan utama dari penetapan ajaran Islam) seperti tertera dalam ilmu uṣūl al-fiqh. Dalam uṣūl al-fiqh, dijelaskan bahwa maqāsid al-sharī'ah merujuk pada lima nilai universal (usūul al-khams), yaitu perlindungan agama (hifž al-din), perlindungan diri (hifz al-nafs), perlindungan akal (hifz al-'aqI), perlindungan keturunan (hifź al-nasl), dan perlindungan harta (hifź al-māI). ${ }^{42}$

Menurut JIL, untuk mengetahui maqāsid, seseorang harus memahami konteks. Pemahaman terhadap konteks ini menurut mereka adalah prasyarat utama untuk menemukan maqāṣid. Bagi JIL, memahami maqāṣid adalah kunci sukses bagi seorang penafsir dalam penafsirannya. ${ }^{43}$

Bagi JIL, untuk merumuskan maqāsid, kita harus mempertimbangkan mașlahah, karena yang terakhir ini adalah dasar bagi penetapan setiap hukum Islam (al-sharī'ah al-Islämiyyah). Oleh karena itu pula maka maslahah bisa menghapus beberapa ketetapan literal teks yang partikular, seperti terkait ayatayat hudūd. Berbeda dengan para sarjana klasik yang meletakkan mașlahah sebagai sumber hukum setelah al-Qur'ān, Sunnah, Ijma' (konsensus), qiyas

${ }^{41}$ Seperti para sarjana al-Qur'an klasik Taha membagi ayat-ayat al-Qur'an pada Makiyyah dan Madaniyyah. Tetapi berbeda dengan dengan para sarjana klasik, menurutnya yang pertama berisi ayat-ayat qat 'i karena berisi nilai-nilai fundamental Islam, sedangkan yang kedua adalah ayat-ayat zanni karena berisi ajaran-ajaran Islam yang teknis-partikular. Lebih jauh, tidak seperti teori nasikh-mansukh klasik, dia berpendapat bahwa bagi era modern ini, ayat-ayat Madaniyah bisa dihapus oleh ayatayat Makiyah. Lihat Mạmud Muhammad TTaha, The Second Message of Islam, Terj. Abdullah Ahmed al-Na'im (Syracuse: University Press, 1996).

${ }^{42}$ Lihat Abd Moqsith Ghazali, et.al., Metodologi Studi Al-Qur'an, 136. Mengikuti Abu Zayd, JIL menambahkan lima maqasid ini dengan tiga hal lain, yaitu rationalisme, liberalisme, dan keadilan. Lihat Mutawalli, H., JIL: Menggugat Digugat (Mataram: LKIM, 2009), 232.

${ }^{43}$ Abd Moqsith Ghazali, et.al., Metodologi Studi Al-Qur'an, 152. 
(analogi), dan seterusnya, JIL menempatkan mașlahah sebelum teks, lagi-lagi, dengan alasan karena ia merupakan prinsip dasar dalam penetapan hukum Islam.

Terkait konsep mașlahah, JIL membagi mașlahah ke dalam dua: subjektif-individual dan objektif-sosial. Yang pertama berkaitan dengan kepentingan personal. Ia dapat ditentukan secara personal dan sifatnya subjektif. Sedangkan yang kedua menyangkut kepentingan publik dan oleh karennya harus ditentukan oleh banyak orang melalui proses musyawarah (shüra). Terkait dengan urusan publik ini, maka JIL membolehkan hasil musyawarah kolektif ('aql al-mujtama') ini menyortir atau mengamandemen bunyi "literal" teks yang sifatnya partikular.

Terlihat dari konsep maqāsid, maṣlahah, dan 'aql al-mujtama', JIL menempatkan akal pada posisi yang sangat tinggi. JIL meletakkan akal sejajar dengan teks, bahkan lebih tinggi. Bagi mereka akal bisa mengamandemen dan merubah makna literal teks. Lebih jauh, bagi JIL, standar kebenaran sebuah penafsiran adalah kesesuaiannya dengan akal manusia. Dalam hal ini JIL mendasarkan idenya pada posisi mulia (takrïm) manusia, seperti disinyalir alQur'an. $^{44}$

Ketiga, terkait tujuan dan hasil penafsirannya. Dari metodologi dan hasil-hasil ijtihad JIL dalam beberapa buku dan websitenya, terlihat jelas bahwa tujuan dan kepentingan penafsiran mereka, sesuai dengan misi awal kelahirannya, adalah ingin menampilkan Islam yang sesuai dengan prinsipprinsip Islam liberal, yaitu kebebasan, liberalisme, sekularisme, kesetaraan jender, dan demokrasi.

Hal ini harus dipahami, bahwa JIL adalah sebuah organisasi yang lahir dan ada dalam konteks partikular Indonesia yang dicirikan dengan maraknya konservatisme, radikalisme dan fundamentalisme Islam pada awal era reformasi. Kelahiran JIL juga adalah respon terhadap maraknya kelompok-kelompok Islam yang menyuarakan penegakkan Syariat Islam, dengan agenda konkritnya yaitu tuntutan dimasukkannya tujuh kata dalam piagam Jakarta ke dalam konstitusi atau undang-undang. Maka tidak mengherankan apabila metode dan penafsiran

${ }^{44}$ QS. Al-Isra: 70:

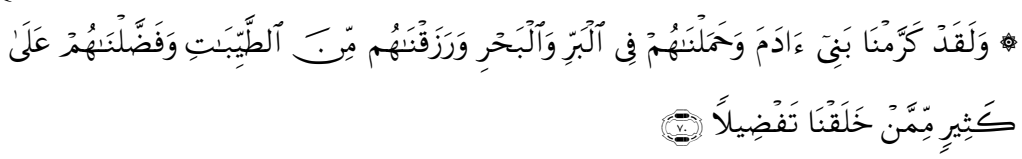

Artinya: "dan Sesungguhnya telah Kami muliakan anak-anak Adam, Kami angkut mereka di daratan dan di lautan, Kami beri mereka rezki dari yang baikbaik dan Kami lebihkan mereka dengan kelebihan yang sempurna atas kebanyakan makhluk yang telah Kami ciptakan.” 
al-Qur'ān JIL mengarah pada paham dan ideologi tertentu, seperti tertera pada pembahasan konsep Syariat Islam dan ayat-ayat ḥudūd berikut ini.

\section{Syariat Islam dalam Perdebatan}

Sebelum masuk pada pemikiran dan penafsiran JIL atas konsep Syariat Islam dan hudūd, sebagai pemetaan wacana, ada baiknya kita meninjau ulang wacana ini dalam konstalasi pemikiran Islam secara teologis-doktrinal dan isu tuntutan penerapannya di Indonesia secara historis-kontekstual. Dengan begitu maka pembahasan diharapkan akan lebih holistik-komprehensif.

Tema Syariat Islam memang tidak pernah berhenti diperdebatkan, termasuk di Indonesia. Untuk konteks Indonesia, isu ini sama tuanya dengan umur negara ini sendiri. Sampai saat ini tidak bisa dimungkiri bahwa masih banyak kelompok masyarakat kita yang menghendaki penerapan Syariat Islam, baik yang berjuang di luar parlemen, seperti HTI, FPI, MMI, PERSIS dan DDII, maupun yang berada di dalam parlamen (melalui partai politik), seperti PKS, PBB, PBR, dan PPP.

Sudah cukup banyak literatur yang menjelaskan tentang pergulatan wacana terkait penegakan Syariat Islam di Indonesia ini. Di antara literatur tersebut adalah buku berjudul Syariat Islam: Pandangan Muslim Liberal, ${ }^{45}$ Formalisasi Syariat Islam di Indonesia: Sebuah Pergulatan yang Tak Pernah Tuntas, ${ }^{46}$ dan buku berjudul Penegakan Syariat Islam karya Rifyal Ka'bah. Tiga buku yang merupakan tulisan para sarjana Indonesia tersebut sudah cukup

${ }^{45}$ Penerbitan buku ini berawal dari diskusi yang diselenggarakan JIL di Puncak, Jawa Barat pada 10-11 Januari 2003. Dengan mengundang pakar, intelektual Muslim, dan para aktivis Muslim, acara ini bertajuk Shari'a: Comparative Perspective. Di antara sarjana yang hadir adalah Abdullahi Ahmed al-Naim (pakar Hukum Islam dan HAM asal Sudan), Azyumardi Azra, KH. Husein Muhammad, M. Syafii Anwar, Fuad Jabali, Ulil Abshar Abdalla, Hamid Basyaib, dan masih banyak lagi. Menariknya, acara ini juga dihadiri oleh M. Ismail Yusanto, juru bicara Hizbut Tahrir Indonesia (HTI), dan Adian Husaini, dari Dewan Dakwah Islam Indonesia (DDII), dua kelompok yang notabene mendukung dan memperjuangkan penegakan Syariat Islam di Indonesia. Lihat Burhanuddin, ed., Syariat Islam: Pandangan Muslim Liberal (Jakarta: JIL, 2003).

46 Masykuri Abdillah, dkk, Formalisasi Syariat Islam di Indonesia: Sebuah Pergulatan yang Tak Pernah Tuntas (Jakarta: Renaisan, 2005). Buku ini berisi tulisan Said Agil al-Munawwar, Masykuri Abdillah, Zainun Kamal, Mujar Ibnu Syarif, Rumadi, Abdul Mun'im DZ, Ahmad Baso, Imam Ghazali Said, Bisri Effendi, A. Tihami, Ghazali Abbas, Nurrohman, Dara Yusilawati, Masdar F. Mas'udi, M. Abdurrahman, Ja'far Umar Thalib, Adian Husaini, dan M. Ismail Yusanto. Buku ini berisi prolog dari Said Agil alMunawwar dan pendahuluan yang berjudul Formalisasi Syariat Islam oleh Masykuri Abdillah, serta tiga bagian pembahasan, yang masing-masing: bagian pertama membahas Syariat Islam dalam konteks modern di Indonesia, bagian kedua membahas formalisasi Syariat Islam dalam konteks otonomi daerah, dan bagian ketiga membahas Syariat Islam dalam perspektif orang-orang ORMAS. 
menunjukkan adanya polemik terkait pro-kontra penerapan Syariat Islam di Indonesia.

Secara umum, terkait penerapan Syariat Islam di Indonesia ini para sarjana Muslim Indonesia dapat dibagi pada dua golongan: mereka yang menolak formalisasi Syariat Islam dan mereka yang mendukung. Kelompok yang pertama biasanya berasal kelompok Muslim liberal, sedangkan yang kedua biasa disebut kelompok Muslim fundamentalis. ${ }^{47}$ Masing-masing dari mereka memperkuat pendapatnya, mulai dari argumen teologis-skripturalis sampai pada argumen historis-politis.

Berbeda dengan kelompok fundamentalis yang sangat menekankan pada pemahaman doktrinal dan tekstual keagamaan, kelompok liberal lebih melihat konsep Syariat Islam secara historis-antropologis. Dengan pendekatan tafsir kontekstual-rasional-substantif, kelompok kedua ini menganggap masalah Syariat Islam bukan semata-mata masalah ketaatan kepada Tuhan (teologis), tetapi lebih dari itu ia menyangkut soal perbedaan tafsir, fikih, relasi MuslimNon Muslim, hubungan negara-agama, masalah ekonomi, politik, dan seterusnya. $^{48}$

Berdasarkan tinjauan historis, kalangan liberal, seperti Nurcholish Madjid, Abdurrahman Wahid dan Ahmad Wahib, melihat bahwa tidak ada model baku dalam sejarah Islam bagi penerapan Syariat Islam $^{49}$ dan oleh karenanya mereka menolak secara tegas penerapan Syariat Islam beserta sistem pemerintahan yang religius-legalistik. ${ }^{50}$

Terkait penerapan Syariat Islam di era modern ini Saiful Mujani, salah seorang pemikir liberal, misalnya telah mencoba membandingkan beberapa negara yang telah menerapkan Syariat Islam di dunia. Dengan standar apa yang

47 Dzulmanni, ed., Islam Liberal \& Islam Fundamental: Sebuah Pertarungan Wacana (Jogjakarta: eLSAQ Press, 2003).

${ }^{48}$ Lihat Halid Alkaf, Quo Vadis Liberalisme Islam Indonesia (Jakarta: Kompas, 2001), 218-240.

${ }^{49}$ Hal ini sejalan dengan pendapat al-Naim. Pemikir asal Sudan ini bahkan mengatakan bahwa istilah syariat Islam seperti kita pahami saat ini itu sendiri tidak ada dalam sejarah intelektual Muslim sampai abad kedua hijriah. Istilah ini bagi generasi pertama Islam, adalah sebuah sistem komprehensif. Ia mencakup persoalah hukum, doktrin, ritual atau ibadah, interaksi dan hubungan sosial atau muamalah (akidah, syariah, dan akhlak) dalam Islam. Jadi, Syariat Islam bukan dalam arti hukum fiqih, khususnya lagi hukum pidana dan perdata, tetapi jalan hidup yang komprehensif. Burhanuddin, ed., Syariat Islam: Pandangan Muslim Liberal, 5. Tentang pembahasan Syariah dan evolusinya, dengan panjang lebar dibahas oleh Fazlur Rahman dalam buku Islam, ter. (Bandung, Pustaka, 1991).

${ }^{50}$ Halid Alkaf, Quo Vadis Liberalisme Islam Indonesia, 230. 
ia sebut dengan indeks kemaslahatan warga, ${ }^{51}$ ia berkesimpulan bahwa negaranegara yang telah melakukan percobaan penerapan Syariat Islam, ternyata tidak memiliki indeks kemaslahatan yang lebih baik dibandingkan dengan negaranegara lain yang tidak menerapkan Syariat Islam, baik itu untuk lingkup Asia maupun (apalagi bila dibandingkan dengan) Eropa dan Amerika. ${ }^{52}$

Dari kacamata politik, kelompok yang menolak penerapan Syariat Islam cenderung melihat bahwa tuntutan Syariat Islam selalu bersifat politis dan bertendensi sektariansime dengan memperlakukan agama sebagai kedok dan syariat sebagai topeng, dan sejauh diamati, mereka tidak pernah menunjukkan agenda yang jelas. ${ }^{53}$

\section{Penafsiran JIL terkait Konsep Syariat Islam dan Ḥudūd}

Kalau kita lihat dari buku-buku dan websitenya, JIL memang telah mendiskusikan banyak hal, mulai dari konsep Islam liberal itu sendiri, penafsiran terhadap teks-teks al-Qur'ān, pluralisme agama, anti-radikalisme, kesetaraan jender, demokrasi, sampai dengan tentang Syariat Islam. ${ }^{54}$ Karena cakupan tema Syariat Islam sangat luas, bagaimana pun pembahasan ini tidak bisa dilepaskan dari tema penting lain seperti terkait soal pemahaman keislaman perspektif JIL secara umum, seperti tentang tafsir atas wahyu atau kitab suci (penafsiran terhadap teks), terkait humanisme (HAM), dan tidak kalah pentingnya juga soal bentuk negara dan sistem pemerintahan.

Secara keseluruhan terkait pandangan keislaman, JIL pada dasarnya mempercayai bahwa Islam harus dipahami sebagai agama yang hidup (living religion). Seperti halnya organisme, menurut JIL, Islam harus dilihat sebagai agama yang dinamis (tidak statis dan kaku). Bagi JIL, Islam harus menjadi agama yang membebaskan (liberatif), bukan agama yang dogmatis-restriktif.

51 Indeks Kemaslahatan yang ia maksud ini diambil dari indikator-indikator pembangunan manusia (human development) yang dirumuskan UNDP, yaitu: Pertumbuhan per-kapita, pemetaan dari pertumbuhan ekonomi yang dapat diukur dari indeks Gini, tingkat pendidikan dengan indikator tingkat melek huruf, harapan hidup (life span), dan kesetaraan jender dapat diukur dari proporsi perempuan yang bekerja mencari nafkah. Serta jaminan atas hak-hak warga yang diukur dari indeks kebebasan sipil (civil liberty). Lihat Burhanuddin, ed., Syariat Islam: Pandangan Muslim Liberal, 21.

${ }^{52}$ Burhanuddin, ed., Syariat Islam: Pandangan Muslim Liberal, 24-39.

${ }^{53}$ Ini adalah pendapat Muhammad Said Al-Asymawi, seorang pemikir liberal Mesir, setelah melihat pengalaman Mesir dalam menerapkan Syariat Islam. Lihat Burhanuddin, ed., Syariat Islam: Pandangan Muslim Liberal, 1.

54 Tema-tema ini dapat kita lihat dalam Luthfi Assyaukanie, ed., Wajah Liberal Islam di Indonesia, (Jakarta: JIL, 2002) dan, Abd. Moqsith Ghazali, ed., Ijtihad Islam Liberal: Upaya Merumuskan Keberagamaan yang Dinamis (Jakarta: Penerbit JIL, 2005). 
Sejalan dengan pandangan ini, JIL mencoba menawarkan penafsiran al-Qur'ān kontekstual seperti telah dijelaskan di atas, yaitu penafsiran yang menekankan nilai etis-religius, bukan penafsiran yang menekankan makna literal teks. ${ }^{55}$ Dengan pemahaman semacam ini, menurut mereka, Islam akan selalu dinamis.

Sejalan dengan pemikiran dan metode tafsirnya yang menolak penafsiran literalis, JIL menolak ajakan kembali kepada al-Qur'ān dan Sunnah yang hanya menekankan pada pembacaan literal, bukan melihat makna substansialnya. ${ }^{56}$ Bagi JIL, makna QS. Al-Ahzab [33]: 36:

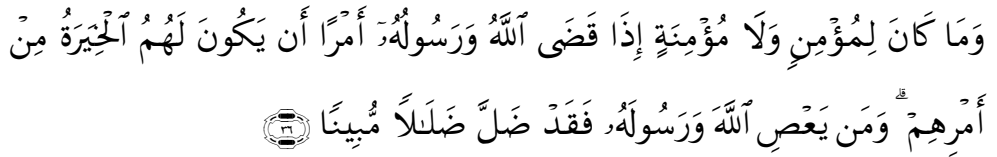

dan QS. al-Maidah [5]: 44, 45, 47:

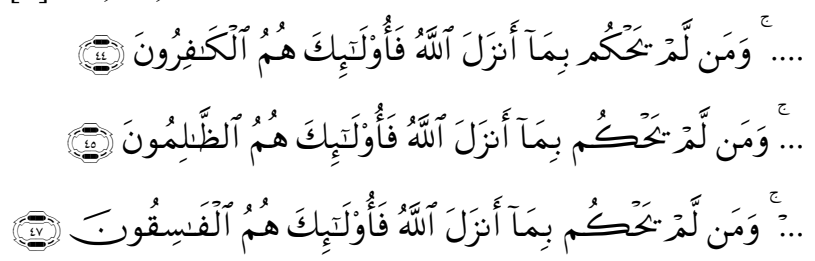

tentang kepasrahan secara total seorang Muslim kepada ketetapan dan hukum Tuhan itu tidak dalam arti literal teks seperti dipahami mayoritas Muslim sekarang, tetapi makna substantifnya. ${ }^{57}$ Baginya, pembacaan tekstual terhadap

${ }^{55}$ Lihat: http://islamlib.com/en/pages/about/. Diakses pada hari Kamis 2 Mei 2013.

${ }^{56}$ Abd Moqsith Ghazali, et.al., Metodologi Studi Al-Qur'ān,135.

${ }^{57}$ Abd Moqsith Ghazali, et.al., Metodologi Studi Al-Qur'ann, 113 dan 133. Terkait ayat-ayat di atas, al-Naim mengatakan bahwa ayat tersebut benar. Tapi ia tidak menjelaskan maksud dari 'apa' yang diturunkan Allah (bimā anzala Allāh). Potongan ayat ini yang menjadi ketidaksepakatan Muslim dalam sejarah. Karena itu ia tidak dapat dimasukkan ke dalam kebijakan publik, karena merupakan kemauan individu. Dan ketika sesorang memaksakan pendapatnya tentang 'apa yang diturunkan Allah' adalah demikian, maka itu bukanlah syariat.

Terkait hal ini, al-Naim menunjukkan kasus perbedaan pendapat antar madzhab fikih. Di Nigeria misalnya, dasar hukuman bagi perbuatan zina adalah atas dasar kehamilan tanpa nikah. Bukti atas perbuatan zina adalah kondisi dan keadaan hamil. Sementara penetapan bukti ini hanyalah khas madzhab Maliki, sedangkan madzhab lain tidak menerimanya. Padahal hal ini adalah masalah hidup atau mati, tapi implementasi hukuman itu tergantung siapa imam madzhab yang diikuti. Selain itu, Naim juga menyebutkan kisah Abu Bakar terkait sebagian orang yang menolak membayar pajak kepada negara, sebagai contoh lain. Abu Bakar, sebagai khalifah pada saat itu merasa berwenang memaksa dan memerangi orang-orang tersebut, sementara sahabat lain, seperti 'Umār, 'A $\bar{i}$, 'Usmān, dan Zubayr, tidak setuju. Dalam perbedaan pendapat ini, alNaim bertanya, manakah yang syariat, melakukan pemaksaan kepada rakyat atau tidak memaksa?. Karena maksud syariat ini sangat luas dan sangat subjektif, maka menurut al- 
teks al-Qur'ān hanya akan mengarah pada penyembahan pada teks (bibliolatry) semata. ${ }^{58}$

Terkait dengan pemahaman JIL terhadap hukum Islam (hudūd), sesuai dengan metode tafsir kontekstual-historis, JIL menafsirkan QS. Al-Nūr [24]: 31dan QS. Al-Ahzāb [33]: 59 tentang jilbab, yang berbunyi:

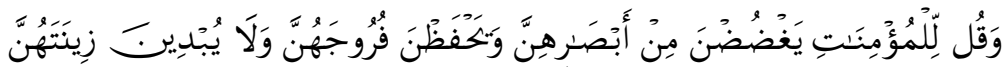

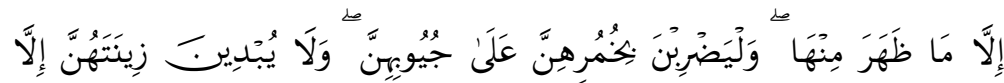

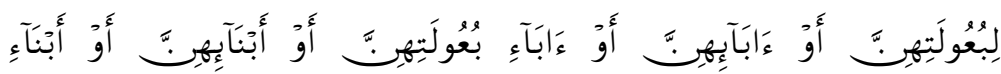

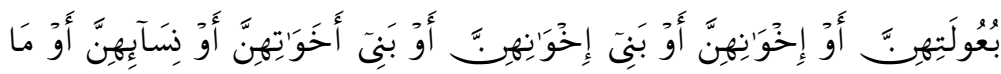

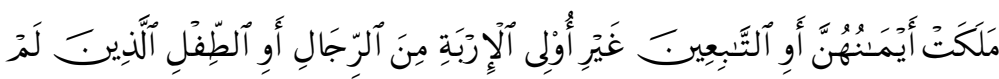

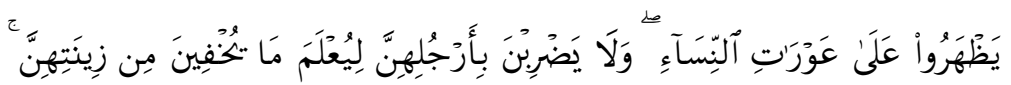

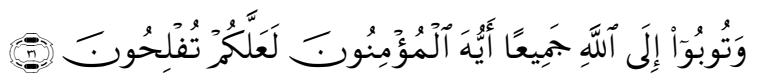

dan berbunyi:

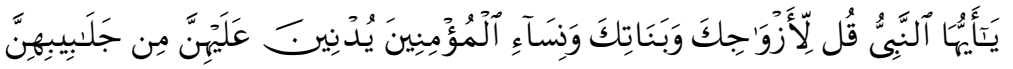

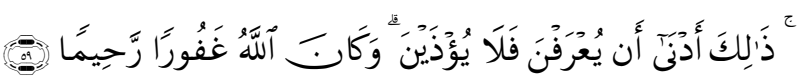

QS. Al-Māidah [3]: 38 tentang hukum potong tangan, yang berbunyi:

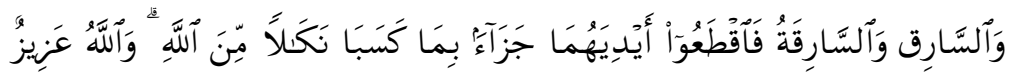

\section{حَكِيمُ}

QS. Al-Baqarah [2]: 178 tentang hukum qișās, yang berbunyi:

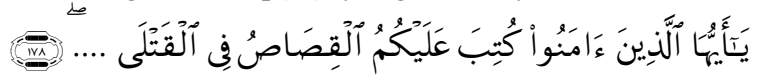

dan QS. Al-Nūr: 2 tentang hukum cambuk, yang berbunyi:

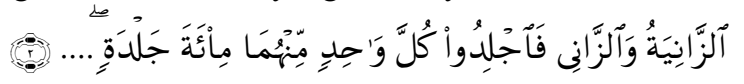

secara kontekstual-historis-substantif. JIL melihat ketentuan hukum partikular tersebut hanyalah merupakan bagian dari budaya Arab, dan oleh karenanya

Naim, syariat tidak bisa dijadikan subjek legislasi. Lihat Burhanuddin, ed., Syariat Islam: Pandangan Muslim Liberal,197.

${ }_{58}$ Abd Moqsith Ghazali, et.al., Metodologi Studi Al-Qur'ān,133 
tidak perlu diikuti. ${ }^{59}$ Dalam konteks ini JIL mengajak untuk melakukan penafsiran yang membedakan antara tradisi Arab lokal dengan nilai-nilai fundamental Islam.

Pandangan ini juga didasarkan pada pembagian atas ayat-ayat yang fundamental (uṣūt), dari yang temporal-kontekstual-terbatas (fuṣū $)$, serta pembedaan antara ayat Makiyyah yang bersifat tetap (qat '’î) dan ayat Madaniyyah yang samar-berubah (zannî̀). Seperti telah dijelaskan di depan, JIL berpendapat bahwa selain dari ayat-ayat tentang ritual seperti shalat, puasa, dan haji, serta aturan terkait makanan dan minuman, semua ayat-ayat hukum yang diturunkan di Madinah harus dilihat sebagai ayat-ayat temporal-kontekstual dan terbatas pada kehidupan masyarakat Arab pada abad ke-7 Hijriah. Ayat-ayat hudū tersebut menurut JIL termasuk kategori ini. ${ }^{60}$

Kemudian, kalau kita lihat dalam proses penafsiran JIL terhadap ayatayat al-Qur'ān, termasuk tehadap ayat-ayat ḥudūd, unsur humanisme (HAM) adalah salah satu hal yang sangat diperhatikan dan menjadi bahan pertimbangan. "Kepentingan" atau kemaslahatan manusia menjadi hal yang sangat diperhatikan. Oleh karena itulah JIL selalu mempertimbangkan nilainilai, seperti pluralisme, kesetaraan jender, dan demokrasi, ${ }^{61}$ yang menurut mereka sesuai dengan hak asasi manusia (HAM). Oleh karena itulah, rupanya, JIL juga menolak beberapa aturan literal hukum al-Qur'an (hiudūd) yang terkesan tidak humanis, seperti hukum potong tangan, hukum cambuk, dan qisas. $^{62}$

Sambil mengatakan bahwa syariah klasik (hud $\bar{u} d)$ seperti hukum potong tangan bagi pencuri, rajam, dan ta'jir adalah zannis, tidak qat ${ }^{\circ}{ }^{63}$ JIL mengatakan bahwa ayat-ayat hudūd tersebut, jangan dipahami secara literal, tapi harus ditafsirkan secara kontekstual dengan memperhatikan maqāsid-nya, yaitu untuk memelihara keadilan dan kebahagiaan bagi umat Muslim pada saat

59 Ulil Abshar-Abdalla, "Menyegarkan Kembali Pemahaman Islam", dalam Dzulmanni, ed., Islam Liberal \& Islam Fundamental: Sebuah Pertarungan Wacana (Jogjakarta: eLSAQ Press, 2003), 2.

${ }^{60}$ Abd Moqsith Ghazali, et.al., Metodologi Studi Al-Qur'ān, 135-6.

${ }^{61}$ Abd Moqsith Ghazali, ed., Ijtihad Islam Liberal, 37-147.

${ }^{6}$ Pendapat JIL ini sesuai dengan pemikiran al-Naim. Terkait dengan hudūd, alNaim mengatakan bahwa hudūd itu seharusnya tidak diterapkan oleh negara. Hadd sebagai hukuman kriminal, harus diterima oleh publik, dan bukan individu. Hadd diterapkan atas muslim sebagai kafarah, tebusan. Ia adalah justifikasi religius-subjektif. Bagaimana bisa hadd yang notabene masuk kategori religius-subjektif diterapkan pada orang yang tidak menyutujuinya? Intinya bagi Naim, hukum itu harus berdasarkan alasan publik, dan bukan keyakinan keagamaan subjektif-individu. Lihat Burhanuddin, ed., Syariat Islam: Pandangan Muslim Liberal, 198.

${ }^{63}$ Mutawalli, JIL: Menggugat Digugat, 110. 
ayat-ayat itu diturunkan. Bagi JIL, makna literal ayat-ayat hudūd ini tidak relevan dengan konteks Indonesia kontemporer. ${ }^{64}$

Terkait dengan tuntutan penerapan Syariat Islam di Indonesia, JIL mengatakan bahwa agama adalah urusan privat, sementara urusan publik harus diusahakan oleh masyarakat melalui sistem yang demokratis. Nilai-nilai universal agama tentu diharapkan dapat memberi kontribusi bagi kehidupan publik, sementara doktrin-doktrin dan praktek peribadatan adalah urusan masing-masing agama. ${ }^{65}$ Lebih jauh terkait dengan sistem politik, menurut JIL, harus ada pemisahan antara otoritas agama dan orotitas politik (negara). Dalam hal ini, sejak kemunculannya, JIL tanpa kenal lelah mendukung sistem demokrasi dan menolak teokrasi. ${ }^{66}$

JIL meyakini bahwa sistem politik Khilāfah Islāmiyah (negara Islam) bukanlah ajaran fundamental Islam. Bagi mereka, tidak ada negara Islam, karena sistem politik pada masa Nabi adalah bagian dari ajaran Islam yang partikular, temporal, dan kontekstual. Dan oleh karena itu, ia bisa dirubah sesuai dengan konteks. Menurut mereka, Khiläfah Islämiyah itu tidak tidak cocok dengan konteks Indonesia, karena Indonesia adalah negara yang pluralistik-majemuk.

\section{Kesimpulan}

Dari pembahasan di atas, terlihat jelas bahwa pemikiran Jaringan Islam Liberal (JIL) tentang konsep Syariat Islam dan ayat-ayat hudūd, bersifat kontekstual. Sesuai dengan cara pandang tentang Islam dan dengan metodologi tafsirnya, JIL memahami konsep Syariat Islam dan ayat-ayat hudūd dalam bingkai Islam yang dinamis-liberalis, penafsiran yang kontekstual-historis, pendekatan humanis, dan sistem pemerintahan demokratis.

Di samping itu, dari kajian ini, diketahui bahwa metodologi tafsir kontekstual JIL berpijak pada: pertama, secara ontologis, JIL menggunakan pendekatan humanis-historis dalam memandang al-Qur'ān (hakikat al-Qur'ān,

${ }^{64}$ Mutawalli, JIL: Menggugat Digugat, 110. Bandingkan dengan pendapat Masdar Farid Mas'udi dalam artikelnya "Meletakkan Kembali Maslahat Sebagai Acuan Syari'ah (Suara Orang NU), dalam Masykuri Abdillah, dkk, Formalisasi Syariat Islam di Indonesia: Sebuah Pergulatan yang Tak Pernah Tuntas, 231.

65 Dzulmanni, ed., Islam Liberal \& Islam Fundamental: Sebuah Pertarungan Wacana, 3.

${ }^{66}$ Mengenai perdebatan tentang sistem pemerintahan di Indonesia, khususnya tentang respon intelektual Muslim Indonesia terhadap konsep demokrasi, bisa dilihat dalam Masykuri Abdillah, Demokrasi di Persimpangan Makna: Respons Intelektual Muslim Indonesia Terhadap Konsep Demokrasi (1966-1993)(Yogyakarta: Tiara Wacana Yogya, 1999). 
konsep pewahyuan dan proses kodifikasinya); kedua, secara epistemologismetodologis, JIL mengutamakan peran akal (rasio) dalam setiap proses penafsirannya, seperti terlihat dalam konsep maqāsid, mașlahah, dan 'aql almujtama' yang menjadi poros penafsirannya; dan ketiga, secara aksiologis, penafsiran JIL cenderung subjektif-ideologis, yaitu menunjukkan kecenderungannya pada ideologi dan kepentingan tertentu. [ ]

\section{Daftar Pustaka}

Abdillah, Masykuri. Demokrasi di Persimpangan Makna: Respons Intelektual Muslim Indonesia Terhadap Konsep Demokrasi (1966-1993). Yogyakarta: Tiara Wacana Yogya, 1999.

--------, dkk. Formalisasi Syariat Islam di Indonesia: Sebuah Pergulatan yang Tak Pernah Tuntas. Jakarta: Renaisan, 2005.

'Abd al-Jabbār, Qạ̣i. Sharḥ fi al-Uṣul al-Khamsah. (Cairo: Maktabah Wahbah, tt.).

Abshar-Abdalla, Ulil. "Menyegarkan Kembali Pemahaman Islam". Dalam Dzulmanni, ed., Islam Liberal \& Islam Fundamental: Sebuah Pertarungan Wacana. Jogjakarta: eLSAQ Press, 2003.

Abū Zayd, Naṣr Hāamid. Naqd al-Khitāàb al-Dỉnī. Kairo: Sina li al-Nashr, 1992.

-------. al-Naș wa al-Sultah wa al-Haqiquah: al-Fikra al-Dïni bayna al-Irādah alMa'rifah wa Irādah al-Haymanah. Beirut: Al-Markaz al-Thaqāfí al'Arabi, 1995.

Ali, Muhamad. "The Rise of the Liberal Islam Network (JIL) in Contemporary Indonesia." The American Journal of Islamic Social Sciences 22:1.

Alkaf, Halid. Quo Vadis Liberalisme Islam Indonesia. Jakarta: Kompas, 2001.

Amal, Taufik Adnan dan Syamsu Rizal Panggabean. Tafsir Kontekstual alQur'an: Sebuah Kerangka Konseptual. Bandung: Mizan, 1989.

Armas, Adnin. Pengaruh Kristen-Orientalis terhadap Islam Liberal: Dialog Interaktif dengan Aktivis Jaringan Islam Liberal. Jakarta: Gema Insani Press, 2003.

al-Ash'ari, Abu al-Hasan. al-Ibanah 'an Usul al-Diyanah. Kairo: Dar al-Taba'ah Darb al-Atrak, tt.

Assyaukanie, Luthfi. Wajah Liberal Islam di Indonesia. Jakarta: JIL, 2002.

Barton, Greg. Gagasan Islam Liberal di Indonesia: Pemikiran Neo-Modernisme Nurcholish Madjid, Djohan Effendi, Ahmad Wahib, dan Abdurrahman Wahid, 1968-1980. Jakarta: Pustaka Antara-Paramadina, 1999. 
Binder, Leonard. Islamic Liberalism: a Critique of Development Ideologies. Chicago and London: The University of Chicago Press, 1988.

Burhanuddin, ed. Syariat Islam: Pandangan Muslim Liberal. Jakarta: JIL, 2003. el-Dardiry, Ramy. "Islam Encountering Enlightenment: Clash or Symbiosis?; A Comparative Analysis of the Dutch and Indonesian Discourse on Liberal Islam". The University of Twente, makalah, tt.

Essack, Farid. The Qur'an: A User's Guide. Oxford: Oneworld Publication, 2007.

al-Farmawī, Abdul Hayy. Al-Bidāya fí Tafsìr al-Mauḍu'î̀. Kairo: Dār Kutub, 1977.

Ghazali, Abd Moqsith, et.all. Metodologi Studi al-Qur'an. Jakarta: Gramedia, 2009.

--------, ed.Ijtihad Islam Liberal: Upaya Merumuskan Keberagamaan yang Dinamis. Jakarta: JIL, 2005.

Iyaz, ‘ATi. al-Mufassirūn wa Manāhijuhum. Teheran: Muassasah Taba'ah, 1919.

Kurzman, Charles. Liberal Islam: a Source Book. New York and Oxford: Oxford University Press, 1998.

Madjid, Nurcholish. Islam Kemodernan dan Keindonesiaan. Bandung: Mizan, 2008.

Mutawalli. JIL: Menggugat Digugat. Mataram: LKIM, 2009.

Muzakki, Akh. "Current debates in the post soeharto Indonesian islam: Examining the Intellectual Base of Liberal and Anti-liberal Islamic Movement.” Jurnal Al-Jāmi 'ah, Vol. 45, No. 2, (2007).

------. "Contestation between Liberalism and Anti-liberalism in the Reformasi Indonesian Islam: Jaringan Islam Liberal and Media Dakwah”. (Makalah, tidak diterbitkan).

Nurdin, Ahmad Ali . "Islam and State: A Study of The Liberal Islamic Network in Indonesia, 1999-2004," New Zealand Journal of Asian Studies 7, 2 (December, 2005).

Palmer, Richard E. Hermeneutics: Interpretation Theory in Schleiermacher, Dilthey, Heidegger, and Gadamer. Evanston, Illinois: Northwestern University Press, 1969.

Rahman, Fazlur. Islam and Modernity: Transformation of an Intellectual Tradition. Chicago: University of Chicago Press, 1982.

Rahman, Yusuf. "The Hermeneutical Theory of Nasr Hamid Abū Zayd”. McGill University Montreal, PhD Dissertation, 2001.

Saeed, Abdullah. Interpreting the Qur'an: Towards a Contemporary Approach. Oxford: Routledge, 2006. 
-------(ed). Approaches to the Qur'an in Contemporary Indonesia. London: Oxford UP in assocication with the Institute of Ismaili Studies, 2005.

-------. The Qur'an: Introduction. New York: Routledge, 2008.

Shaltut, Mahmud. al-Islam Aqidah wa Shari'ah. Beirut: Dar al-Fikr, 1996.

Taha, Mahmud Muhammad. The Second Message of Islam. Terj. Abdullah Ahmed al-Na'im. Syracuse: University Press, 1996.

Taji-Farouki, Suha, (ed.). Modern Muslim Intellectuals and the Qur'ān. Oxford: Oxford University Press, 2004.

Wahib, Ahmad Bunyan. "Liberal Islam in Indonesia: The Attitude of Jaringan Islam Liberal Towards Religous Freedom and Pluralism". Leiden University: MA Thesis, 2004.

al-Zarkashi, Burhan al-Din Muhammad ibn Abd Allah. al-Burhān fí 'Ulūm alQur'ān. Beirut: Dar al-Ma'arif li al-Tiba'ah wa al-Nashr, 1972, vol. 1. 